\title{
Feminist practical theology and (un)making structural violence against immigrant women and families
}

\author{
Teologia prática feminista e o (des)fazer a violência \\ estrutural contra mulheres e famílias imigrantes
}

\section{Susanne Johnson*}

Perkins School of Theology, Dallas, Texas, United States of America

\begin{abstract}
A key thesis of this essay is that exploration of the construct of structural violenceespecially as iterated in Johan Galtung's notion of the triangle of violence-can help elucidate the theological concept of systemic or social sin, and thereby help Christians generate a more adequate ethical response to issues and dilemmas in immigration debates in the U.S. today. The notion of structural evil and sin can proffer insight into the reality of complex webs and entanglements in structural violence that enshrouds the lives and journeys of unauthorized Latino/a immigrants into the United States, and into the role of U.S. citizens in perpetuating such violence. Structural violence, seen
\end{abstract}

*SJ: Doctor, e-mail: susannej@smu.edu 
theologically as social sin, is a conceptual key to "critical seeing" of political, social, legal, and economic structures and policies that drive forced economic immigration in the first place, and also to exposing the moral oblivion and blindness that thwarts the church from offering hospitality and justice to unauthorized immigrants. I argue that because structural violence originates in the vastly unequal distribution of power and privilege among human agents, which systematically advantages elite power brokers at the expense of people on the lowest rungs of society, then repentance from structural violence must entail collective efforts toward redistributing power, and ensuring more equitable access to resources needed for human flourishing. The primary practice and discipline dedicated to this radical task is faith-based community organizing.

Keywords: Structural Violence. Latina immigrants. Justice. Faith-based Organizing.

\section{Resumo}

Uma tese fundamental deste ensaio é que a exploração da construção da violência estrutural - especialmente em referência à noção de Johan Galtung sobre o triângulo da violência pode ajudar a elucidar o conceito teológico do pecado sistêmico ou social e, assim, ajudar os cristãos a gerar uma mais adequada resposta ética a questões e dilemas nos debates sobre imigração nos EUA hoje. A noção de mal estrutural e pecado pode revelar a visão de realidade de teias complexas e enredos na violência estrutural que envolve as vidas e viagens de imigrantes latinos não autorizados nos Estados Unidos e o papel de cidadãos americanos na perpetuação dessa violência. A violência estrutural, vista teologicamente como pecado social, é uma chave conceitual para a "visão crítica" de estruturas e políticas sociais, jurídicas, políticas e econômicas que impulsionam a imigração econômica forçada em primeiro lugar, e também para expor o esquecimento moral e a cegueira que impede a igreja de oferecer hospitalidade e justiça a imigrantes não autorizados. Eu argumento que, porque a violência estrutural se origina na distribuição muito desigual de poder e privilégio entre os agentes humanos, que vantajosamente beneficia os corretores de poder de elite à custa de pessoas nos mais baixos níveis da sociedade, então o arrependimento da violência estrutural deve envolver esforços coletivos para redistribuir o poder, garantindo um acesso mais equitativo aos recursos necessários para o florescimento humano. A principal prática e disciplina dedicada a esta tarefa radical é a organização comunitária baseada na fé.

Palavras-chave : Violência estrutural. Imigrantes latinos. Justiça. Organização baseada na fé. 


\section{Introduction}

I write this essay from the vantage point of feminist practical theology which takes as its starting point and critical principle the liberation, wellbeing, and equitable flourishing of women and their children and families, with particular concern for those relegated to invisibility and immiseration on the lowest rungs of society. The commitment and focus of emancipatory feminist practical theology is not on unbelievers of history, but rather on the nonpersons, the nonsubjects who have been denied voice and say-so in the institutions that shape their daily lives. In this perspective, Christian faith converts, "becoming a praxis of solidarity with those who suffer and working for the transformation of human agency and social structures" (CHOPP, 2007, p. 3-4). Feminist practical theology seeks to render visible not only pain and suffering, but also Spirit-breathed hope and love, and creative resistance against violence and oppression.

Guided byemancipatory commitments, this essayis groundedin and informed by the privileging of voices, journeys, stories, and testimonies of unauthorized Latina immigrants and their children and families, whose lives are constrained by structural violence related to forced economic migration. This essay is guided by a methodology that unfolds through four interrelated phases: (1) firsthand immersion in concrete social reality where there is expressed pain and suffering related to unauthorized immigration into the U.S.; (2) description, analysis, and interpretation of what is going on-with efforts to unmask policies and ideologies that drive unauthorized immigration and produce injustice and suffering; (3) theological interpretation of unjust social reality and structural violence; (4) formulation and enactment of ecclesial response aimed at effective redress of immediate needs, as well as collective engagement in solution-based strategies aimed for structural transformation, in deep solidarity with the people most adversely affected by the structural sin of unjust and chaotic immigration practices and policies. 


\section{Driven from Home: Forced Economic Immigration}

The North American Free Trade Agreement (NAFTA), which lowered commerce barriers between the United States, Canada, and Mexico, came into effect in 1994. NAFTA's proponents promised it would not only create more U.S. jobs, but also would benefit Mexican citizens by increasing their access to cheaper imported goods, and by creating jobs for them and raising their wages. But to the contrary, NAFTA devastated Mexico's rural economy, destroyed small and medium-sized businesses (in retail, food processing, and light manufacturing), compounded rather than reduced poverty-doubling it in households headed by womenand drove up rates of unauthorized immigration from Mexico into the U.S. (Public Citizen, 2015a).

Mexican farmers were unable to compete with the cheaper, subsidized corn imported from the U.S. While between 1995 and 2004 the U.S. government gave U.S. farmers nearly US $\$ 42$ billion in corn subsidies, neoliberal economic practices of the World Bank forced the Mexican government to eliminate corn subsidies to their local farmers. Prices paid to Mexican farmers for their corn plummeted by sixty-six percent, and forced many off their farms (Public Citizen, 2015b). Before NAFTA, millions of Mexican families lived in rural villages, farming plots of land called ejidos, a positive legacy of the Mexican Revolution's land reforms (PERRAMOND, 2008). Constitutionally, this land could not be sold or seized for debt. But NAFTA propelled a change that allowed the sale and consolidation of this land into large farms that could be purchased by U.S. agribusiness and other foreign corporations (PERRAMOND, 2008). Farms disappeared, jobs disappeared, and wages dropped so precipitously that the income of a farm laborer today is one-third of what it was before NAFTA (Public Citizen, 2015a). More than 2.5 million Mexicans lost their land or their livelihoods due to NAFTA's impact. Subsequently, "many of these rural Mexicans emigrated, swelling the ranks of the 12 million illegal immigrants living incognito and competing for low-wage jobs in the United States" (Public Citizen, 2015a).

Following China's entry into the World Trade Organization (WTO) in 2001, many U.S. corporations did an about-face, and abandoned Mexico and 
its US $\$ 5$ per day labor cost to take advantage of China's US $\$ 1$ per day wages, causing the number of manufacturing jobs in Mexico to further plummet. Today, according to the World Bank, over half the Mexican population, and over 60 percent of the rural population, lives below the poverty line.

Meanwhile, in 2005 the U.S. signed into effect the Central America Free Trade Agreement (CAFTA), an expansion of NAFTA to five developing Central American countries-Guatemala, El Salvador, Honduras, Costa Rica, and Nicaragua, later adding the Dominican Republic and renaming the agreement CAFTA-DR (GLOBAL EXCHANGE, 2004). As with NAFTA, proponents of CAFTA promised that the deal would bring economic prosperity to the region, decrease violence, and reduce immigration to the U.S. But similar to what happened in Mexico, Central American family farmers - who constitute a significant portion of the workforcewere unable to compete with highly subsidized U.S. agribusiness, and consequently were displaced, uprooted, and forced into the migrant stream. Evidence suggests that CAFTA ended up contributing to the region's economic stagnation, social upheaval, and sharp uptick in drug violence, gang warfare, and forced economic migration, including rampant anti-union violence, wage theft, and other labor abuses in Guatemala, where at least 68 union activists have been murdered over the course of seven years without a single arrest (DIAZ, 2014). CAFTA provided legal prerogatives and protections for transnational corporations, but not for indigenous farmers and laborers.

Most Americans do not comprehend that it is a complex interplay of an outdated, broken and chaotic system of immigration policies and practices, and U.S. neoliberal trade policies that exploit human and environmental resources in other countries, as exemplified in NAFTA and CAFTA, which creates conditions that drive unauthorized immigration into the U.S. in the first place. As David Bacon insists, the U.S. immigration debate needs to add to its discourse what happens to undocumented migrants before they cross borders - the push-pull dynamics and systemic violence that displace them and force them into motion (BACON, 2008, p. 67). Fortunately, the right to stay home, the right to not migrate, has become a grassroots social movement that envisions a world wherein migration is not forced by the violence of 
poverty, exploitation by transnational corporations, and environmental destruction (BACON, 2013, p. 278).

\section{Border Crossings and Perilous Journeys}

Around the time NAFTA went into effect, the United States started militarizing the nearly 2,000-mile U.S.-Mexico border through deterrence projects, such as Operation Gatekeeper in San Diego, CA (1994). Today, the U.S. government spends more on border patrol than on all other federal criminal law enforcement agencies combined (NICHOLSON, 2017). The deterrence strategy was to deliberately force unauthorized migrants to risk their very lives in efforts to cross the border, by forcing them into less patrolled areas - the most remote, dangerous terrain of mountainous and desert regions of the four states forming the border, viz., Texas, New Mexico, Arizona, California. But out of economic desperation to feed, clothe, and house their families, migrants cross anyway, by relying on the assistance of a coyote-smugglers who charge thousands of dollars per immigrant to get them across the border and deliver them to a presumably safe spot. Many immigrants sell their homes and all their possessions to raise money to pay the coyote. Immigrants with no resources take out loans from loan sharks, entering into veritable indentured servitude.

The treacherous journeys all too often end up with migrants drowning in the Rio Grande River; suffocating in overcrowded cargo transports; losing limbs from mishaps in jumping on and off moving train cars or falling off the back of insecure pickup trucks; dying from fatal dehydration or suffering permanent kidney damage; dying from hypothermia or hyperthermia; undergoing high rates of robbery, and physical and sexual violence en route; being abandoned in the middle of the desert; being subjected to inhumane conditions during mass incarceration in for-profit detention centers; and suffering many other life-and-death assaults on bodily integrity and human dignity. Thousands of migrants have died on the U.S. side of the border, and there are makeshift memorials scattered across the desert. Research on border enforcement reveals the correlation of higher annual averages of deaths with heightened patrol. The International Federation for Human 
Rights has ruled that these deaths constitute strong evidence that the U.S. is violating human rights by maintaining Operation Gatekeeper; other human rights organizations have reached the same conclusion (BERNARD, 2008).

In previous decades undocumented border crossers were primarily Mexican men who left behind their spouses, young children and extended families to seek employment in the U.S. and send back "remittances" (money sent to immediate families and relatives for food, shelter, and clothing, and community resources). Central Americans are now the majority of unauthorized migrants, and there has been an upswing in mothers with young children, and also an uptick in unaccompanied children from El Salvador, Guatemala, and Honduras (murder capital of the world), who seek to escape from gang violence, organized crime, economic deprivation, and recruitment by youth gangs, drug cartels, and sex trafficking rings (NICHOLSON, 2017).

\section{Gendered Risk: Sexual Violence against Undocumented Women}

Today, half the immigrants from Central America and Mexico into the U.S. are women, who are three times as likely as men to die during border-crossing attempts. Sexual assault and rape of women crossing the border is so routine that most women use contraceptives during their journey to avoid an unwanted pregnancy. Given the strong chance that if she resists sexual advances along the way she will either be abandoned out in the remote desert by the coyote, or incur a violent physical confrontation, many women "agree" from the outset of negotiations to have sex with the coyote in exchange for help, protection, and safe delivery at the agreed-on destination (MARRUJO, 2008, p. 229). Not only are undocumented female immigrants routinely subjected to sexual assault en route across the borders, they also often end up working in predatory environments - the agricultural sector is a prime example-where they continue to be sexually assaulted, harassed, raped, and otherwise victimized by supervisors who exploit their undocumented status with threats to call authorities if they report the abuse (WU, 2013). 
The U.S. Department of Justice estimates that at least 68 percent of all sexual assault and rape victims in the U.S. never report the crime. Due to the combined influence of tenuous immigrant status, cultural conditioning, variable understanding of what constitutes sexual violence, lack of knowledge about protections afforded by U.S. law, and other factors, this figure is higher for undocumented Latina immigrants (ZADNIK; CHIARA; CUEVAS, 2014). In some Latino cultural traditions, sexual assault and violence against women is framed as crime against the honor of the family, rather than crime against the physical integrity and human rights of the female victim. Aside from fearing they will be shunned and shamed, undocumented female immigrants who are raped or assaulted explain that they are reluctant to report it to authorities and seek formal help for reasons such as they fear losing their job, fear being blacklisted by their employer, fear retaliation, fear deportation if they speak up, fear they will not be believed, fear and distrust the police, and fear that their husbands or boyfriends will blame them for what happened (REINA; LOHMNA; MALDONADO, 2014). The fear of deportation "is particularly acute for women with children, as they fear separation from their US citizen children and loss of ability to support their families" (HUMAN RIGHTS WATCH, 2012).

While many undocumented immigrant women victimized by sexual violence are not aware of it, there are special legal protections available to them under U.S. immigration law. When harmful activity against a woman consists of rape, incest, domestic violence, or certain other violent crimes, she may be eligible for what is known as a $\mathrm{U}$ visa; or a $\mathrm{T}$ visa in cases of sex-trafficking or labor trafficking. These are temporary visas that allow undocumented female immigrants to avoid deportation and gain legal status in the U.S. and, in some cases, eventually earn permanent resident status on the condition that she helps law enforcement in the investigation and prosecution of the violent crime against her (DEPARTMENT OF HOMELAND SECURITY, [20-?]).

The church's concrete response to immigrant female victims of violence must include efforts to reduce the multiplebarriers that discourage them from reporting their experiences of violence and from seeking help, both formal and informal. There also needs to be multi-pronged efforts 
at community education about the special visa provisions (PITTS, 2013). A major national study of domestic violence against Latina women found that there is a high need for public awareness and education, including efforts aimed not only at victims, but also friends and family (CUEVAS; CHIARA, 2010). "In their outreach efforts providers should recognize that shame and the desire to maintain privacy is a driving force behind the lack of disclosure," as is lack of legal status and language barriers (CUEVAS; CHIARA, 2010, p. 19).

\section{Conceptualizing Violence}

Adequate Christian ethical response to violence inflicted on immigrant women and families depends in large measure on how violence is understood. The literature on violence in the lives of immigrant women mainly addresses domestic and intimate partner violence-often discussed as interpersonal violence (IPV) — which has reached pandemic proportions (RAJ; SILVERMAN, 2002). While the literature is generating valuable concrete suggestions as to how congregations and faith-based advocacy groups can best provide accompaniment to immigrant women tyrannized by sexual and physical violence (cf. INGRAM et al., 2010), this essay seeks to set these direct, interpersonal forms of violence within a larger framework that brings to light other manifold forms of violence against the bodily integrity and human dignity and rights of Latinas and their families - forms rendered invisible by narrow focus on direct, oneon-one acts of sexual and physical violence.

When a female immigrant is raped, or forced against her will to perform certain sexual acts, or is physically beaten, or even controlled and harmed by threats of violence, there clearly is an identifiable perpetrator who can be held accountable. But in the case of grinding poverty and environmental spoliation wrought by exploitative practices of transnational corporations; forced economic migration; displacement and dispossession from one's homeland; deaths and drownings at the border; dehumanizing stereotypes and discrimination against migrants; relegation to a permanent underclass; forced social invisibility ("living 
in the shadows"); lack of political voice; emotionally traumatic effects of workplace raids and sudden deportations and ripped apart families; prolonged separation of children from their parents; incarceration in for-profit detention centers under inhumane conditions; and other massive suffering among immigrant populations, including children-there is no single, easily identifiable violator to hold accountable, and often no actual illegal crime has been committed against immigrants, thereby rendering invisible many forms of violence that hurt and harm immigrant women and families.

\section{Johan Galtung's Triangle of Violence}

In his groundbreaking work in the field of peace studies, Norwegian sociologist Johan Galtung distinguished between direct violence, where the instigator of an act of violence can be traced to a person or persons, and structural violence, where there may not be any person who directly harms another person. In structural violence, the violence is built into systems and institutions and their policies and practices, and shows up as unequal distribution of power and privilege, unequal access to resources and conditions needed to thrive and flourish, and unequal life chances (GALTUNG, 1969). "Direct violence is an event," Galtung notes, while "structural violence is a process" (GALTUNG, 1990, p. 294).

Galtung also identified a third distinct concept, cultural violence, which refers to the symbolic sphere of society-exemplified in ideologies, worldviews, public discourse, education, religious traditions and artifacts, art, and so on, that get used to justify, legitimize, and normalize structural violence, and to make institutionalized practices and policies seem natural, inevitable, and even divinely ordained (GALTUNG, 1990).

There are, for example, a number of social imaginaries and myths America lives by - such as American Exceptionalism, meritocracy, City on a Hill, neoliberalism, nationalism - which are used to justify neocolonialist political and economic practices that drive undocumented migration in the first place and which, in one way or another, incite and fuel negative attitudes and violent acts against undocumented immigrants. Media spectacles during and after the 2016 U.S. presidential election cycle reveal how these 
myths are used for political gain, and how easily they get conflated with Christian narratives and values. Because topics such as politics, economics, classism, and immigration policy are so taboo in U.S. churches, pastors are impeded in helping people deconstruct false narratives and see how systems operate, much less equip them to renounce and reconstruct those systems, and instate more life-giving alternatives.

As a feminist, I am especially concerned with the patriarchal dimension of cultural violence-referring to the set of social relations between men, which, though quite hierarchical, establishes some sort of solidarity that enables all men to dominate at least some women (HARTMAN, 2006, p. 185). In this hierarchy, all workers are positioned on a sharp gradient and pyramid of power and privilege in the economic system, determined by intersections of gender, class, race, ethnicity, and immigrant status. Neoliberal capitalists have an interest in segmenting the labor market along these lines, and playing workers against one another. This thwarts solidarity and collective power and protest, while ensuring an endless supply of cheap labor and a system of blame, where poor working class whites and blacks accuse and hate Latino immigrants for supposedly taking their jobs. The unequal relations of power and privilege in this hierarchy comprise interlocking forms of racism, ethnocentrism, classism, and sexism, which means, among other things, that one may "benefit" from structural violence along one axis, while being victimized by it along another.

Galtung integrated the three conceptions of violence-direct, cultural, and structural-and iterated them as a "triangle of violence". He suggests that structural violence and cultural violence give rise to direct violence - for example, sexual assault on Latina immigrants — then events of direct violence double back and reinforce structural and cultural violence. Further, he believes that because of its pervasiveness and hiddenness, structural violence is ultimately more deadly and destructive than direct violence, for it does not affect as many people as do cultural and structural violence-which is not to discount the insidiousness of acts of direct violence on immigrants.

The phenomenon of the triangle of violence is like an iceberg, the vast majority of which is submerged, with only a small tip visible as events 
of direct violence. Thus, as Rob Nixon points out, we are accustomed to conceiving of violence solely or mainly as events and actions that are instantly visible and immediate in time, and explosive and spectacular. The fiery spectacle of the collapsing towers on 9/11 was burned into the U.S. national psyche as the definitive image of violence associated with unauthorized immigration, ramping up the social construction of unauthorized Latino immigrants (as well as Muslim immigrantseven those with proper papers) as would-be terrorists, illegal invaders, violent criminals, as well as economic threats, lazy freeloaders, and carriers of disease. Nixon coined the phrase "slow violence" to highlight the submerged, stealth workings of cultural and structural violence which derives its insidiousness, in part, from the unequal attention we give to the spectacular which happens in plain sight, in contrast to the unspectacular which is hidden but nonetheless as deadly (NIXON, 2007, p. 6). As a result of these dynamics, emotionally, morally, and politically speaking the different dimensions of the triangle of violence possess "unequal heft" (NIXON, 2007, p. 3).

When structural violence begins to break into public awareness, the wealthy power elites who benefit from it briskly deflect the dawning awareness onto more sensational acts of direct violence (MOELOBEDA, 2013, p. 74). Through inflammatory rhetoric, they keep public attention focused on isolated violent crimes committed by unauthorized immigrants, never mentioning the greater prevalence of direct violence committed by U.S. citizens against immigrants. Research shows that immigrants, authorized and unauthorized alike, commit considerably less crime than do U.S. born citizens (NICHOLSON, 2017). The scapegoating and blaming and deflecting onto direct violence keeps citizens distracted from the more dangerous and insidious structural and cultural violence which "influences the nature and distribution of extreme suffering" (FARMER, 2004, XIII). 


\section{Structural Violence as Structural Sin}

An understanding of violence expanded beyond a narrow focus on direct acts can help Christians theologically correct a common understanding of sin as individual acts of wrongdoing. Indeed, scripture depicts a more complex and far-reaching notion of sin as disorientation from right relationship with God, which engenders disorientation from right relationship with self, others, and all of creation (MOE-LOBEDA, 2013, p. 58). But even this expanded notion confines or reduces sin to a condition of individuals.

In a seminal essay, Kristen Heyer traces how the scope and meaning of sin has been expanded in Roman Catholic theological thought (HEYER, 2010). Whereas Pope John Paul II's theological emphasis and legacy helps guard against downplaying individual culpability in sinful situations, core insights from Latin American liberation theology guard against downplaying the impact and constraints that unjust social structures exert on personal agency and so-called free will. In contemporary theology, both Roman Catholic and Protestant, there is wide consensus that sin is manifest not only in individual lives, but also in social structures, and that there is a dialectical relationship between personal sin and social sin. As José Ignacio González Faus avers, "When human beings sin, they create structures of sin, which, in their turn, make human beings sin" (HEYER, 2010, p. 422). Institutions, structures, and ideologies created and sustained by persons, and persons shaped by institutions, structures, and ideologies, are alike guilty of sin and therefore in need of transformation (HEYER, 2010, p. 422).

Our theological framework needs to incorporate both the voluntary and willful dimensions of social sin, and involuntary dimensions, referring, in part, to the sin in which we participate unwittingly and unconsciously simply by living as we do, and going about our daily lives. We unconsciously internalize ideologies - such as nationalism-that are at variance with Christian faith and that distort our values and consciousness, and then undertake both individual and collective unjust decisions and actions on such basis. The involuntary dimension of structural sin also has to do with our willful ignorance and passive acquiescence to its reality. Silence is consent.

In the case of immigration, there exists both the sinful reality of unjust institutions and policies (structural violence) that contribute to 
border crossings, and ideologies and symbolic systems (cultural violence) that normalize unjust realities while also perpetuating moral oblivion and blindness to harm being inflicted. Structural sin includes both the harm that is done, and our silent, passive acquiescence to and oblivious participation in it. Drawing on Dietrich Bonhoeffer's reflections on the widespread complicity with fascism during Third Reich Germany, Cynthia Moe-Lobeda emphasizes the hiddenness of structural evil. "The cloaked nature of structural evil," she writes, "is at its very heart" (MOE-LOBEDA, 2013, p. 66). As Bonhoeffer put it, the ability of evil to "appear disguised" confirms its wickedness. People perpetrating structural evil enable it to hide by denying its existence, by defending it as historical necessity, by allowing it to remain subconsciously submerged, and by other means; this is sinful collusion. Heyer similarly argues that "to allow ourselves to remain ignorant of the plight of small farmers in Mexico, the fatal realities of the yet-unfortified stretches of border, or the treatment of undocumented immigrants in detention centers is arguably, in this age of globalized technology and media, entering the realm of culpable ignorance" (HEYER, 2010, p. 429).

In her book, Fall to Violence, feminist theologian Marjorie Suchocki, makes an understanding of structural violence central to her concept of sin. She rejects traditional views of original sin as rebellion against God through pride. Instead, she proposes that sin fundamentally is participation-whether deliberate or not-in unnecessary violence against the wellbeing of any aspect of the earth or any of its creaturely inhabitants (SUCHOKI, 1995). Inclusive well-being is the norm against which sin is to be measured. Sin is defiance against inclusive well-being, whereby we are robbed, or rob others, of well-being and agency. Sin attacks creaturely well-being, destroys mutuality, and inflicts ill-being. Ultimately, violence against the well-being of any creature or any part of creation is sin against a relational God who creates and co-suffers with creation.

\section{Hospitality, Justice-Making, and Social Salvation}

Even as sin is seen in many trajectories of Christian theology as both personal and social, salvation is also conceptualized in both individual and systemic terms. In liberation theology, salvation 
refers, in part, to liberation from the oppression and violence that is systemically inflicted on those who Ignacio Ellacuria refers to as "the crucified people" of human history. "What is meant by crucified people here is that collective body, which as the majority of humanity owes its situation of crucifixion to the way society is organized and maintained by a minority that exercises its dominion through a series of factors, which taken together and given their concrete impact within history, must be regarded as sin" (CAMPESE, 2008, p. 282). The crucified people live in the shadows, and languish and die prematurely due to lack of adequate nutrition, healthcare, rest, and other resources necessary to live fully and flourish. They are the exploited, oppressed, marginalized, disposable, and abandoned people whose suffering is not self-inflicted or due to natural causes. "The crucifixion of these peoples is the product of the oppressive and sinful use of power by a few persons...the crucified exist because there are crucifiers" (CAMPESE, 2008, p. 284). By their very existence they reveal the enormity of the deadly reality of sin in the world (CAMPESE, 2008, p. 285). With Campese, I assert that undocumented Latino/a migrants are foremost among the groups of exploited people who are being crucified in the U.S. today; salvation for them will include freedom from structural violence and freedom for life abundant. In this essay, I want to emphasize salvation as also including the liberation and transformation of people who, whether by action or inaction, perpetrate systemic violence and take part in keeping migrants on their crosses. Salvation for them means they will repent and renounce structural evil, and cooperate with God's Spirit, and work collectively to rebuild a more just society-in effect, taking migrants down from their crosses.

If structural violence is created by accumulated decisions and actions of human beings over time, then it can also be dismantled by human action-yet this must be through exercise of collective agency, not simply aggregated individual effort. Our identity as beings created in the image and likeness of God means that God's own Spirit is breathed into us and the whole created order, and is the source of our spiritualethical power and agency to engage in justice-making neighbor lovethe heart of our baptismal vocation. "Love implies active commitment," writes Moe-Lobeda, "to the well-being of whom or what is loved. Where 
people suffer under systemic injustice, seeking their well-being entails seeking to undo that injustice" (MOE-LOBEDA, 2013, p. 57).

\section{Hospitality: A Sufficient Christian Ethic?}

It is my thesis that the sinful triangle of violence inflicting so much ill-being on Latino/a immigrants challenges the discourse in current calls for the church's theological and ethical response to immigration debates, calls which stress the urgency of recovering the ancient biblical practice of hospitality. Certainly we need to be more proactive in efforts to reach across differences, and welcome and embrace immigrants - whether or not documented-and value their gifts and treat them as equal partners; recognize and respect their alterity; comprehend the complexities today in negotiating hybrid identities; strive for "unity without uniformity;" celebrate diversity as a gift of God; offer immigrants accompaniment and solidarity in their suffering, while also recognizing them not as victims only but as active agents and bearers of faith and hope.

Actually, there are large multicultural congregations in the Dallas area which do not lack hospitality to immigrants. Their membership includes immigrants who are well-to-do executives in corporations headquartered in north Dallas, such as Exxon Mobil, Frito-Lay, JC Penney, and others. What these churches seem to lack is hospitality to poor uneducated, undocumented, Mexican and Latino/a immigrants. Scripture does not allow us to disconnect God's option for the immigrant from God's option for the poor, lest we coopt and corrupt the practice of hospitality as a cover-up for reproducing class power and privilege. Hospitality seen simply as celebration of diversity is not an entirely adequate ethical response to poor working-class, exploited immigrants.

While hospitality is indeed a profound and indispensable ecclesial practice, no matter how theologically robust, it cannot carry the full freight of Christian ethical response to the entwined forms of violencedirect, structural, and cultural-inflicted on the bodies and personhood of immigrants, especially women and the working-class poor. Hospitality was not what put an end to the institution of slavery in the U.S., and 
to the lynching of black people; rather, it was another ancient biblical practice-justice-making. I venture there is biblical warrant to claim that justice-making is a practice so decisive to authentic worship of God that when this practice is absent, other ecclesial practices become colonized, corrupted, self-serving - and hospitality becomes a hollowed out affair that keeps structural arrangements of class power and privilege hidden and intact. In Hebrew scripture, justice-making has to do with securing a rightly ordered, collective way of life that conforms to God's own character as the Utterly Just One, and with enacting God's promised Shalom in all societal spheres - social, economic, political, religious. Kwok Pui-Lan and Joerg Rieger note that a core biblical meaning of justice is "bringing those who have been treated unjustly back into the community while challenging those who have promoted injustice and curbing their transgressions" (RIEGER; PUI-LAN, 2012, p. 64). Drawing insights from various scholars, and linking them to Alasdair MacIntyre's notion of practice, I suggest that,

Justice-making can be seen as an ecclesial and prophetic practice and theological means of grace, comprised of complex, coherent, and cooperative activity through which persons and communities intentionally and strategically confront social, cultural, economic, political, and religious systems which hurt and harm or inhibit the wellbeing and flourishing that God intends for the earth and all its inhabitants, with the aim of transforming these systems toward a vision of basileia, God's promised future of full flourishing in a Shalom community of just relationships, full inclusion, freedom, interdependence, and shared power.

The theological symbol basileia, as Elisabeth Schüssler Fiorenza reminds us, connotes a political vision that appealed to the oppositional imagination of people victimized by the Roman imperial system. It envisions an alternative world free of hunger, poverty, and domination of those who are most vulnerable, especially those for whom scripture attests that God shows special concernimmigrants, widows, orphans, and the poor (FIORENZA, 2010, p. 96).

For their authenticity and faithfulness, the practices of justice-making and hospitality must presuppose and depend not only on the presence and vitality of each other, but also on congregational engagement in other morally formative practices and means of grace, given that justice-making 
requires the formation of spiritually sustained people who have phronesispractical wisdom, and virtue of character needed for moral discernment of complex, ambiguous, and novel situations, along with commitment to act in courageous, costly, and concrete ethical ways in the public square. As Moe-Lobeda suggests, "discernment is the disciplined art of coming to know ever more fully the mystery that is God, coming to see ever more clearly the historical realities of life on earth, and holding these two in one breath, so that we may come closer to knowing where God is at work in these earthly realities" (MOE-LOBEDA, 2004, p. 65). We are called to discern and participate in God's own missio Dei in the world. When Christians seek to reduce violence against immigrants through hospitality and justice-making, we not only are mediating God's all-inclusive love and grace, we also are posturing our very own selves as recipients of it - for God, not us, is seen theologically as the prevenient actor in the means of grace.

It is my further thesis that there is no better way for congregations to engage people in the ecclesial practice of justice-making than through the venue of faith-based community organizing (also known as institution-based, and broad-based organizing). The major purpose of organizing is to provide workingpoor people and their allies a venue through which they generate the collective political power and skill needed to hold elected officials and corporate elites of society accountable to the well-being of the most vulnerable families, in this case, unauthorized Latino/a immigrants. One way power is built is through a membership base of institutions rather than individuals, including churches, temples, mosques, public schools, labor unions, nonprofits, and neighborhood associations. As Jeffrey Stout points out, "So long as ordinary people remain unorganized, they will lack the power to prevent bosses, developers, and bankers from achieving economic dominance and translating it into political dominance. A citizens' organization aims to enhance the power of ordinary people to achieve basic social relationships that are not marred by domination. Exercising this power involves taking advantage of the institutions they have already created" (STOUT, 2010, p. 58).

In contrast to the highly visible Black Lives Movement in the U.S., faithbased organizing is going on below the radar screen; hence, lacking media attention, many people do not know what a remarkable thing is happening. Sociologically, the threshold for long-term impact of a social movement is 
active participation of one percent of a nation's population. Today, faith-based organizing collectively represents one and a half percent of Americans, and is growing (WOOD; PARTRIDGE; FULTON, 2011). This is rare in American history.

For poor immigrants and other exploited people, faith-based organizing groups function as "universities of hope" that teach the arts, dispositions, and skills of public engagement, grounded theologically in resources from the respective faith traditions to which members belong. Organizing begins not with abstract theology and theory, but rather with building face-to-face relationships with diverse others across divides of race, class, gender, religion, and immigrant status. Through storytelling and disciplined listening, persons share and entrust their private pain to one another, discern how the personal is indeed connected to the political, and then work collaboratively to translate their personal pain into collective public action for the common good. In faith-based organizing, transformation of individuals and the transformation of institutions and systems goes hand-in-hand. Over and over again, women in organizing groups-especially Hispanic and Latina immigrants, documented and undocumented alike, and women of color-describe how involvement helped them discover and use their own public voice. A study by the Institute for Women's Policy Research found that interfaith organizing groups provide supports and resources many women need to overcome internalized oppression, and inner fears and lack of self-confidence, based on histories of exclusion, violence, and religiously sanctioned silencing, subordination, and second-class treatment (CAIAZZA, 2006).

\section{Conclusions}

In order to focus and sharpen the Church's prophetic witness in the world, it must unmask and explicitly name the sinful realities being inflicted on migrants, diminishing their self-agency and their access to the flourishing God intends. Even so, given the insidious suffering caused by unjust immigration policies in the U.S. and its imperialism abroad, it is not enough that we scholars, along with the wider Church, simply name and have a good conceptual perspective on what is going on in regard to structural violence, 
for this alone is not capable of reducing vast asymmetries of power, and overcoming class exploitation and other structural injustices. These ills can be overcome only by active spiritual and political struggle in deep solidarity across lines of class, gender, race, religion, immigrant status, and other differences. I agree with Stout's claim that the ever-escalating exploitation and imbalance of power between ruling elites and working-class people is the main source of ills in U.S. society, and that "it can be set straight only if broad-based [interfaith] organizing is scaled up significantly, only if it extends its reach much more widely throughout American society than it has to date" (STOUT, 2010, p. 286). Robert Linthicum, author of the best introductory book available for evangelical Christians interested in faithbased organizing, writes that, "The task of the church is to come alongside the poor and join with them in their struggle to deal with the forces that are exploiting their community. Society will never be changed if we do not take the battle to the powerful and demand of them responsible redistribution of wealth and power. ...That's what Jesus did. And that's what we're called to do as well" (LINTHICUM, 2006, p. 294).

\section{References}

BACON, D. Illegal people: how globalization creates migration and criminalizes migrants. Boston: Beacon Press, 2008.

BACON, D. The right to stay home: how US policy drives Mexican migration. Boston: Beacon Press, 2013.

BERNARD, A. United States-Mexico walls, abuses, and deaths at the borders: flagrant violations of the rights of undocumented migrants on their way to the United States. Paris: International Federation for Human Rights, March, 2008.

CAIAZZA, A. Called to speak: six strategies that encourage women's political activism. Washington, D.C.: Institute for Women's Policy Research, March 31, 2006.

CAMPESE, G. Cuanto mas? the crucified peoples at the U.S.-Mexico border. In: GROODY, D. G.; CAMPESE, G. (eds.). A promised land, a perilous journey: theological perspectives on migration. Notre Dame: University of Notre Dame Press, 2008. p. 271-298. 
CHOPP, R. S. The praxis of suffering: an interpretation of liberation and political theologies. Eugene, OR: Wipf \& Stock Publishers, 2007.

CUEVAS, C. A.; CHIARA, S. Final report: sexual assault among Latinas (SALAS) study. (Document No. 230445). Washington, D.C.: National Institute of Justice, 2010.

DEPARTMENT OF HOMELAND SECURITY. U.S. Citizenship and Immigration Services. Resources for victims of human trafficking \& other crimes. [20-?]

DIAZ, M. G. Guatemala: 68 Union Leaders Murdered before a Single Arrest. In: Panam Post, 2014. Available in: <https://panampost.com/marcela-estrada/2014/06/03/guatemala-68-union-leaders-murdered-before-a-single-arrest/>. Access: 02 July 2017.

FARMER, P. Pathologies of power: health, human rights, and the new war on the poor. Berkeley: University of California Press, 2004.

FIORENZA, E. S. Critical feminist biblical studies: remembering the struggles, envisioning the future. In: HUNT, M. E. New feminist Christianity: many voices, many views. Woodstock, VT: Skylight Paths, 2010. p. 86-99.

GALTUNG, J. Violence, ace, and peace research. Journal of Peace Research, v. 6, n. 3, p. 167-191, 1969.

GALTUNG, J. Cultural violence. Journal of Peace Research, v. 27, n. 3, p. 291-305, 1990.

GLOBAL EXCHANGE. Central American Immigrant Organizations Oppose CAFTA. Press Release. May 27, 2004.

HARTMAN, H. Capitalism, patriarchy, and the subordination of women. In: LEVINE, R. F. Social class and stratification: classic statements and theoretical debates. New York: Rowman \& Littlefield, 2006. p. 183-192.

HEYER, K. E. Social sin and immigration: good fences make bad neighbors. Theological Studies, v. 71, n. 2, p. 410-436, 2010.

HUMAN RIGHTS WATCH. Cultivating fear: the vulnerability of immigrant farmworkers in the US to sexual violence and sexual harassment. 2012.

INGRAM, M. et al. Experiences of immigrant women who self-petition under the Violence against Women Act. Violence against Women, v. 16, n. 8, p. 858-880, 2010. 
PITTS, K. M. Latina Immigrants, Interpersonal Violence, and the Decision to Report to Police. Journal of Interpersonal Violence v. 29, n. 9, p. 1661-1678, 2014. Available in: <http://journals.sagepub.com/doi/pdf/10.1177/0886260513511700>. Access: 02 July 2017.

LINTHICUM, R. C. Building a people of power: equipping churches to transform their communities. [S.1.]: Authentic and World Vision, 2006.

MARRUJO, O. R. The gender of Risk: Sexual violence against Undocumented Women. In: GROODY, D. G.; CAMPESE, G. (eds.). A promised Land, a perilous journey: theological perspectives on migration. Notre Dame: University of Notre Dame Press, 2008.

MOE-LOBEDA, C. D. Public Church: for the life of the world. Lutheran Voices. Minneapolis, MN: Augsburg Fortress, 2004.

MOE-LOBEDA, C. Resisting structural Evil: love as ecological-economic vocation. Minneapolis: Fortress, 2013.

NIXON, R. M. The American Presidents Series: The 37th President, 1969-1974. Por Elizabeth Drew. New York: Times Books, 2007. (Library of Congresss Catalogingin-Publication Data Drew, Elizabeth).

NICHOLSON, M. P. Gravestones of Worcestershire: memorials and inscriptions. [S.1.]: Create Space Independent Publishing Platform, 2017.

PERRAMOND, E. The rise, fall, and reconfiguration of the Mexican ejido. Geographical Review, v. 98, n. 3, 2008, p. 356-371.

PITTS, K. M. Latina Immigrants, Interpersonal Violence, and the Decision to Report to Police. Journal of Interpersonal Violence, n. 22, dec. 2013.

PUBLIC CITIZEN. NAFTA's Broken Promises 1994-2013: Outcomes of the North American Free Trade Agreement. [2015a]. Available from: <https://www.citizen. org/sites/default/files/naftas-broken-promises.pdf>. Access: 02 July 2017.

PUBLIC CITIZEN. Failed Trade Policy \& Immigration: Cause \& Effect. [2015b]. Available from: <https://www.citizen.org/sites/default/files/failed-trade-policy-and-immigration.pdf>. Access: 02 July 2017.

RAJ, A.; SILVERMAN, J. Violence against immigrant women: the roles of culture, context, and legal immigrant status on intimate partner violence. Violence against Women, v. 8, n. 3, p. 367-398, 2002. DOI: 10.1177/10778010222183107. 
REINA, A. S.; LOHMNA, B. J.; MALDONADO, M. M. "He said they'd deport me": factors influencing domestic violence help-seeking practices among Latina immigrants. Journal of Interpersonal Violence, v. 29, n. 4, p. 593-615, 2014. DOI: 10.1177/0886260513505214.

RIEGER, J.; PUI-LAN, K. Occupy religion. New York: Rowman and Littlefield Publishers, 2012.

STOUT, J. Blessed are the organized: grassroots democracy in America. Princeton, NJ: Princeton University Press, 2010.

SUCHOCKI, M. H. The fall to violence: original sin in relational theology. New York: Continuum, 1995.

WOOD, R. L.; PARTRIDGE, K.; FULTON, B. Building bridges, building power: developments in institution-based community organizing. Longmont, CO: Interfaith Funders, 2011.

WU, A. Hidden in the Harvest. [S.1.]: The Center for Investigative Reporting, 2013. ZADNIK, E; CHIARA, S.; CUEVAS, C.A. Violence against Latinas: the effects of undocumented status on rates of victimization and help-seeking. Journal of Interpersonal Violence, p. 1-13, 2014. DOI: 10.1177/0886260514564062.

Received: 07/21/2017

Recebido: 21/07/2017

Approved: 12/16/2017

Aprovado: 16/12/2017 